\title{
Kajian DNA Rekombinan pada Vaksin DNA dan Vaksin Subunit Protein
}

\section{Study of Recombinant DNA in DNA Vaccines and Protein Subunit Vaccines}

\author{
Tri Panjiasih Susmiarsih \\ Department of Biology, Faculty of Medicine, YARSI University, Jakarta \\ Jalan Letjen. Suprapto, Cempaka Putih, Jakarta 10510 \\ Telephone 021-4206674, 4206675, 4206676 \\ Corresponding author: tri.panjiasih@yarsi.ac.id
}

\begin{abstract}
Abstrak
Vaksin telah dikenal sebagai substansi yang digunakan untuk menstimulasi sistem imun. Saat ini, perkembangan vaksin sudah mencapai generasi vaksin DNA dan vaksin subunit protein.Teknologi perancangan vaksin digunakan dalam mengembangkan berbagai jenis vaksin dengan pendekatan biologi molekular yaitu menggunakan teknik DNA rekombinan yang memerlukan sarana vektor, DNA target, enzim restriksi dan ligasi serta sel inang. Studi ini bertujuan mengkaji teknik DNA rekombinan dalam pembuatan vaksin DNA dan vaksin subunit protein.
\end{abstract}

Kata Kunci: DNA rekombinan, vaksin, subunit protein

\begin{abstract}
Vaccines have been known as substances that are used to stimulate the immune system. At present, the development of vaccines has reached the generation of DNA and protein subunit vaccines. Vaccine design technology is used for developing various types of vaccines through the molecular biology approaches. The recombinant DNA techniques require vector, target DNA, restriction enzymes and ligase and host cells. This study aims to know the recombinant DNA techniques for making DNA vaccines and protein subunit vaccines.
\end{abstract}

Key words : recombinant DNA, vaccine, protein subunit

\section{Pendahuluan}

Vaksin telah lama dikenal sebagai suatu substansi yang digunakan untuk memperoleh respon imun terhadap mikroorganisme patogen. Berbagai jenis vaksin kini telah banyak dikembangkan melalui pendekatan teknologi perancangan vaksin yang mengalami perkembangan cukup pesat untuk mengatasi masalah-masalah yang berhubungan dengan kesehatan. Vaksin generasi pertama menggunakan mikroba patogen yang dilemahkan telah banyak digunakan, namun alasan pertimbangan keamanan maka dikembangkanlah vaksin generasi kedua, vaksin generasi pertama seringkali bermutasi kembali menjadi virulen yang menimbulkan efek tidak diinginkan pada sel inang (Nascimente \& Leite, 2012). Vaksin generasi kedua adalah vaksin 
yang mengandung mikroorganisme yang dimatikan dengan zat kimia tertentu, biasanya menggunakan formalin atau fenol, dalam penggunaannya vaksin ini sering mengalami kegagalan tidak menimbulkan respon imun tubuh.

Untuk mengatasi berbagai kelemahan yang terjadi pada penggunaan vaksin generasi pertama dan kedua, dikembangkan vaksin generasi ketiga, yaitu vaksin rekombinan subunit protein. Vaksin subunit protein dibuat melalui teknik DNA rekombinan untuk memproduksi fragmen antigenik dari mikroorganisme. Seiring dengan kemajuan teknologi DNA rekombinan, maka dikembangkan vaksin generasi keempat yaitu vaksin DNA. Makalah ini secara khusus akan membahas DNA rekombinan dalam pembuatan vaksin DNA dan subunit protein.

\section{DNA Rekombinan}

Vaksinasi merupakan cara pencegahan penyakit infeksi yang terbukti paling efektif, baik ditinjau dari segi biaya atau pun intervensinya terhadap masyarakat. Vaksin didefinisikan sebagai bahan biologi, antara lain dapat berupa peptida, protein, polisakarida, polinukleotida, virus atau organisme utuh lainnya, yang dapat mempengaruhi terbentuknya imunitas terhadap penyakit tertentu. Vaksin telah terbukti dapat menurunkan laju mortalitas penyakit infeksi seperti mealase, polio dan difteri (Kumar et al. 2013).

Penelitian dan pengembangan teknologi vaksin sudah memasuki era teknologi modern dengan pendekatan molekular. Jenis vaksin yang berbeda yang telah dibuat dan digunakan secara komersial saat ini, antara lain : a. Vaksin konvensional : vaksin hidup (live attenuated vaccine) dan vaksin inaktif (killed vaccine)

b. Vaksin rekombinan : vaksin subunit (protein rekombinan), yang berupa protein total atau bagian polipeptida yang imunogenik, dan vaksin DNA.

c. Vaksin antigen termurnikan : vaksin polisakarida

Vaksin yang telah dibuat secara komersial belum sepenuhnya digunakan pada manusia, sebagian digunakan pada hewan. Beberapa vaksin yang telah disetujui penggunaannya pada manusia yang berasal dari organisme virus dan bakteri dapat dilihat pada Tabel 1.

Vaksin rekombinan dibuat melalui teknologi DNA rekombinan yang pada dasarnya merupakan tehnologi pengklonaan gen yang direkayasa lebih lanjut untuk menghasilkan produk protein yang diinginkan. Pengklonaan gen adalah suatu proses memasukan DNA atau gen asing ke dalam suatu sel inang dengan bantuan vektor (Wong, 1997). Tujuan pengklonaan gen ini adalah untuk memperbanyak gen yang identik. Pengklonaan gen dilakukan dengan cara menyisipkan gen yang ingin diperbanyak ke dalam vektor untuk membentuk suatu DNA rekombinan yang mampu bereplikasi di dalam sel inang (Griffiths et. al. 1999).

Secara rinci, pengklonaan gen meliputi empat tahap utama, yaitu konstruksi DNA (Deoxyribonucleic acid) rekombinan, tranformasi, seleksi sel klona, dan pengisolasian klona DNA rekombinan yang membawa gen yang diinginkan (Strachan \& Read, 1999). Sumber DNA, vektor dan sel inang merupakan komponen penting dalam pengklonaan gen (Gambar 1). 
Tabel 1. Vaksin dari virus dan bakteri yang sudah disetujui penggunaannya pada manusia (Nascimento \& Leite, 2012)

\begin{tabular}{llll}
\hline & Live attenuated & Killed inactivated & Subunit \\
\hline Viral & Vaccinia & Polio (IPV) & Hepatitis B (HepB-surface antigen) \\
& Polio (OPV) & Rabies & Human papilloma virus (HPV) \\
& Yellow fever & Influenza & \\
Measles & Hepatitis A & \\
Mumps & & \\
Rubella & & \\
& Influenza & & \\
& Rotavirus & & Tetanus (toxoid) \\
& BCacterial (tuberculosis) & Bordetella pertussis (whole cell) & Diphtheria (toxoid) \\
& Salmonella typhi (oral) & Cholera & Neisseria meningitidis (polysaccharide) \\
& Bacillus anthracis & Bordetella pertussis (acellular) \\
& & Streptococcus pneumoniae, 23 valent \\
& & (polysaccharide) \\
& & Heemophilus influenzae, type b (Hib) \\
& & (polysaccharide) \\
& & Neisseria meningitidis (polysaccharide conjugate) \\
& & Streptococcus pneumoniae, heptavalent \\
& (conjugate polysaccharides) \\
& & Salmonella typhi Vi (capsular polysaccharide) \\
\hline
\end{tabular}

aLicensed by national regulatory agencies such as ANVISA in Brazil or FDA in the USA. OPV = oral polio vaccine; IPV = inactivated polio vaccine; $B C G$ = bacillus Calmette-Guérin.

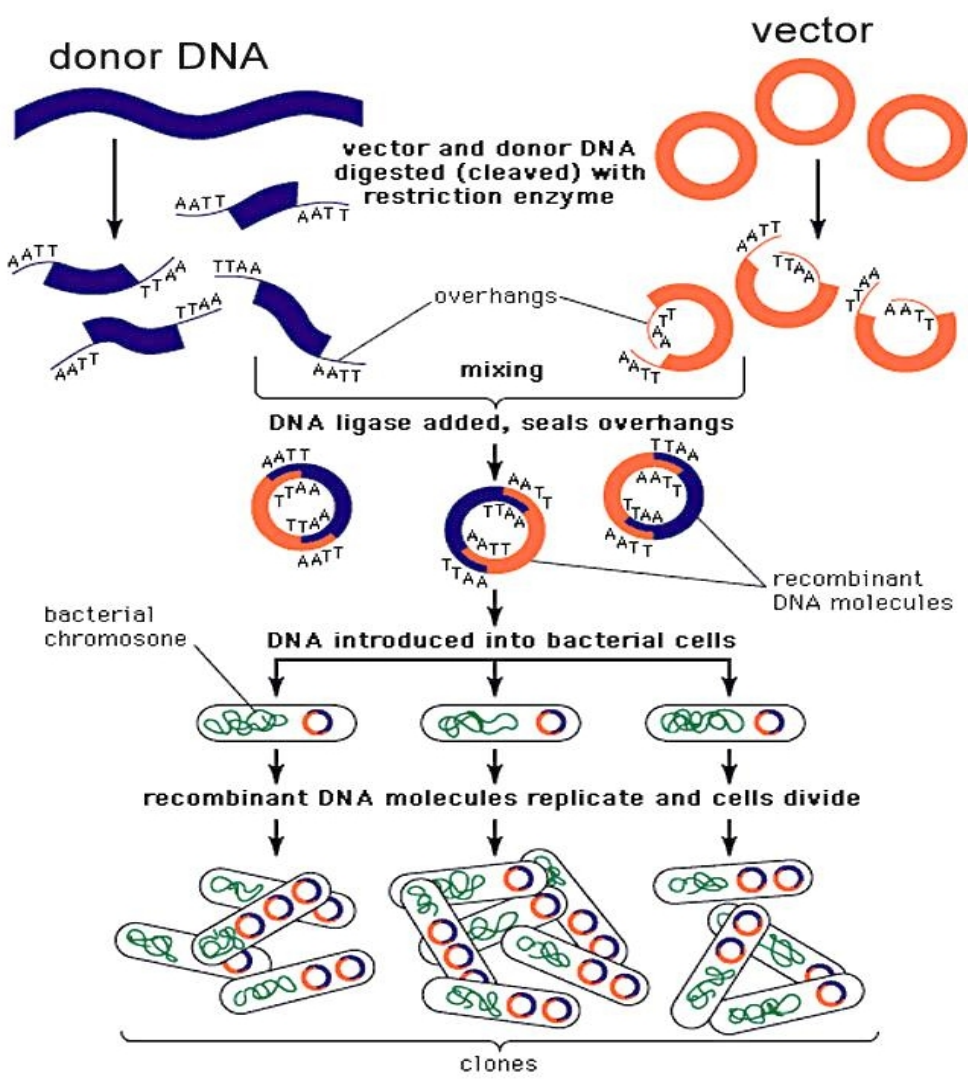

Gambar 1. Proses Pengklonaan Gen. Pengklonaan gen melibatkan DNA target sebagai donor dan vektor sebagai perangkat pembawa gen terget untuk membentuk DNA rekombinan. Selanjutnya vektor rekombinan ini ditransformasi ke sel inang untuk direplikasikan membentuk klona. 
Konstruksi DNA rekombinan meliputi beberapa tahap antara lain isolasi fragmen DNA sebagai target yang akan disisipi, restriksi dan ligasi DNA target dan vektor, transformasi vektor ke sel inang dan analisis DNA rekombinan dalam sel inang. Fragmen DNA target yang ingin diperbanyak dapat diperoleh dengan cara mengisolasi genom atau mengisolasi mRNA sebagai substrat untuk transkrip balik membentuk DNA komplementer (cDNA, complementary deoxyribonucleat acid). Isolasi DNA genom dilakukan dengan teknik PCR (polymerase chain reaction) standar dan cDNA diperoleh dengan teknik RT PCR (real time polymerase chain reaction). Setelah fragmen DNA diperoleh, vektor kloning dipersiapkan untuk dapat disisipi DNA target. Vektor kloning yang umum digunakan adalah plasmid. Dalam konstruksi DNA rekombinan, plasmid yang berbentuk sirkuler dipotong (restriksi) dengan enzim endonuklease restriksi, selanjutnya DNA target disisipkan dan diligasi ke dalam plasmid (Gambar 2).

Setiap enzim endonuklease restriksi memiliki situs pengenalan pemotongan yang berbeda dan sangat spesifik. Enzim endonuklease restriksi yang berbeda, memiliki situs pemotongan yang berbeda, namun ada beberapa jenis enzim endonuklease restriksi yang diisolasi dari sumber yang berbeda memiliki situs pemotongan yang sama. Enzimenzim endonuklease restriksi yang memiliki situs pemotongan yang sama disebut isochizomer (Radji, 2011). Sikuens basa DNA pada situs pemotongan memiliki urutan basa yang sama pada untai DNA heliks ganda, yang dikenal dengan sekuens palindromik. Hasil pemotongan enzim endonuklease restriksi ada dua macam yaitu menghasilkan ujung tumpul (blunt) dan ujung lengket (overhang, sticky) atau kohesif (gambar 3).

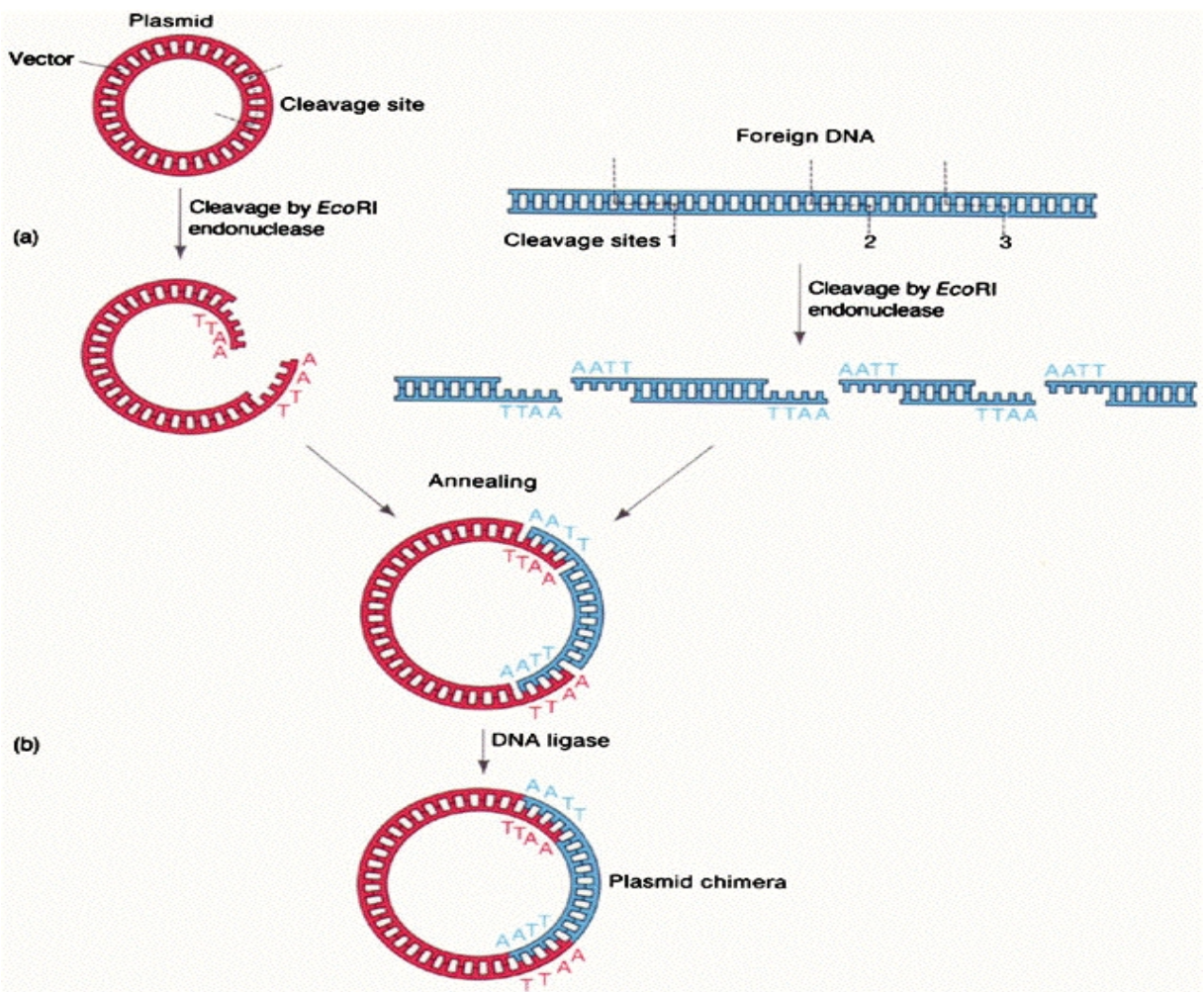

Gambar 2. Kontruksi DNA rekombinan. (a) Enzim restriksi endonuklease EcoRI memotong plasmid dan DNA target di situs pemotongan spesifik. (b) DNA ligase menggabungkan plasmid dengan DNA target membentuk plasmid chimera. 


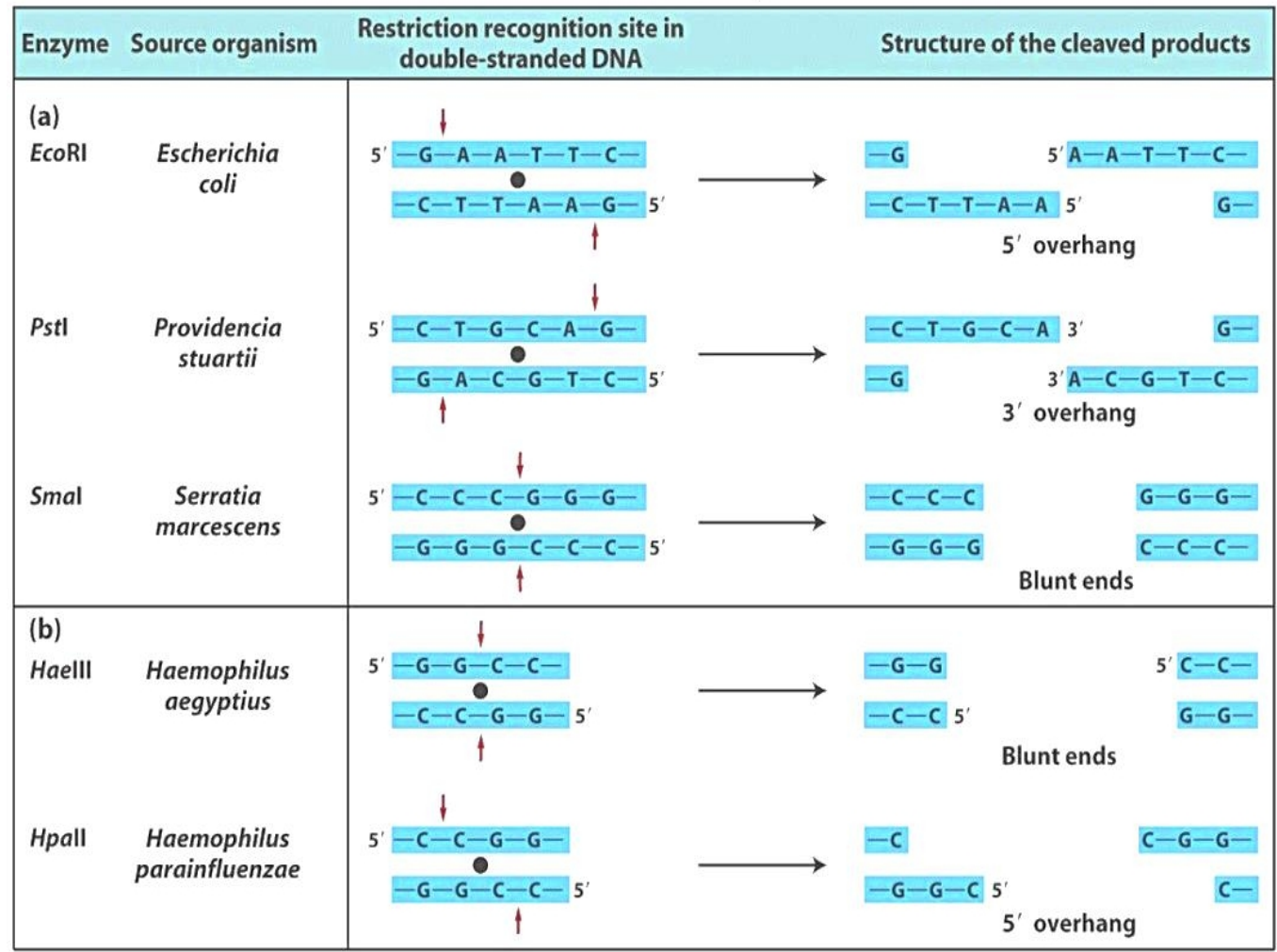

Gambar 3. Beberapa Contoh Enzim retriksi. Hasil pemotongan enzim retriksi menghasilkan pola 5' overhang, 3' overhang (ujung lengket) dan blunt end (ujung tumpul).

Berdasarkan jumlah basa nukleotida yang terlibat pemotongan, enzim restriksi endonuklease dibagi menjadi 3 golongan yaitu: (1) 6-cutters memiliki situs pemotongan yang spesifik pada 6 nukleotida, (2) 8-cutters,situs pemotongan spesifik pada 8 nukleotida dan (3) 4-cutters, situs pemotongan spesifik pada 4 nukleotida (Metzenberg, 2002).

DNA ligase adalah enzim yang digunakan untuk menggabungkan (ligasi) dua potong DNA (DNA target dan DNA plasmid) secara kovalen. Salah satu enzim yang paling banyak digunakan adalah T4 DNA ligase. Reaksi ligasi terjadi antara gugus $3^{\prime} \mathrm{OH}$ dari salah satu untai DNA dengan gugus fosfat dari untai DNA partner. Reaksi ini menggunakan ATP sebagai energi. Ligasi DNA hanya dapat terjadi secara efisien antar dua ujung fragmen DNA yang bersesuaian (kompatibel). Cara ligasi ini terutama digunakan untuk menyisipkan sepotong DNA ke dalam vektor kloning.

Enzim DNA Topoisomerase I berfungsi sebagai enzim restriksi dan enzim ligase. Topoisomerase I dari Vaccinia virus secara spesifik mengenali situs spesifik dan memotong gugus fosfodiester setelah sekuens pentamer 5'CCCTT pada satu untai. Energi dari pemutusan gugus fosfodiester tersimpan oleh formasi ikatan kovalen antara fosfat 3 ' dari untai yang terbelah dan residu tirosil dari topoisomerase I. Ikatan fosfo-tirosil antara DNA dan enzim dapat rusak oleh hidroksil pada ujung 5' GTGG, yang dapat diinvasi oleh dsDNA, perusakan ini melepaskan enzim topoisomerase. Vektor TOPO melakukan modifikasi dari ide tersebut dengan penambahan 4 nukleotida sekuens overhang (GTGG) dan memerlukan penambahan basa nukleotida (CACC) di posisi ujung 3' untai tunggal pada 
DNA target untuk proses ligasi (Invitrogen, 2010).

Transfer plasmid chimera yang mengandung DNA rekombinan ke dalam sel inang merupakan tahap yang penting pada teknologi DNA rekombinan. Beberapa spesies bakteri yang sering digunakan sebagai sel inang dalam industri bioteknologi antara lain adalah Bacillus subtilis, Eschericia coli, Saccharomyces cerevisiae (Radji, 2011). Tipe sel inang yang digunakan disesuaikan dengan tujuan dari pengklonaan. Escherichia coli merupakan salah satu sel inang prokariot yang umum digunakan dalam proses pengklonaan. Escherichia coli banyak digunakan karena mudah dalam penanganan dan mudah diperbanyak, memiliki banyak strain, dan dapat menerima banyak jenis vektor (Nicholl, 2002). Beberapa cara transfer DNA ke dalam sel inang antara lain (1) transformasi, dengan tehnik kejutan panas, elektroporasi dan konjugasi; (2) transfeksi; (3) mikroinjeksi dan (4) mikroprojektil.

Seleksi klona pembawa gen target bertujuan membedakan koloni sel yang mengandung gen yang diinginkan dengan koloni sel yang tidak mengandung gen yang diinginkan. Salah satu cara seleksi klona pembawa gen target adalah dengan uji resistansi terhadap antibiotik. Vektor yang mengandung gen resisten terhadap antibiotik, setelah ditransformasi ke dalam sel inang, maka sel inang juga akan mengekspresikan sifat resisten tersebut, sehingga hanya koloni sel inang yang mengandung vektor tersebut dapat tumbuh pada medium agar berisi antibiotik (Brooker, 2005; Melcher, 2001).

Ampilisin merupakan salah satu contoh antibiotik yang digunakan untuk seleksi klona pembawa gen target. Gen resisten ampisilin pada plasmid TOPO mengkode protein $\beta$ - lactamase. Protein $\beta$ lactamase akan disekresikan bakteri dalam medium dan akan menghidrolisis ampisilin, menonaktifkan antibiotik tersebut sehingga dapatdigunakan untuk seleksi klona (Invitrogen, 2010). Plasmid puC8 mengandung gen LacZ yang menyandi enzim $\beta$-galaktosidase, enzim ini memecah X-gal menjadi galaktosa dan 5-bromo-4-chloroindigo (biru). Koloni Escherichia coli yang membawa puC8 akan berwarna biru bila ditumbuhkan pada media yang mengandung $\mathrm{X}$-gal.

\section{Vaksin DNA}

Transfer DNA plasmid secara langsung ke dalam jaringan mencit tanpa sistem penghantaran khusus telah berhasil dilakukan pertama kali pada tahun 1990 (Wolff et al., 1990). DNA plamid yang disuntikkan secara intra muskular ke dalam tubuh mencit tersebut ternyata dapat memproduksi protein yang disandi oleh sekuen DNA yang terdapat dalam DNA plamid tersebut di dalam jaringan mencit. Penelitian berikutnya telah membuktikan bahwa DNA dapat dimasukkan langsung secara in vivo untuk menghasilkan protein yang dikehendaki sesuai dengan sekuen DNA yang menyandi ekspresi protein tersebut (Wolff et al., 1990). Sejak saat itu diyakini bahwa metode transfer DNA secara in vivo dapat diaplikasikan baik untuk terapi gen maupun untuk vaksinasi.

\subsection{Konstruksi Plasmid DNA Vaksin}

DNA plasmid merupakan produk bioteknologi generasi baru yang sudah masuk di pasaran untuk tujuan terapi maupun tindakan preventif. Produksi dan aplikasi DNA plasmid meliputi 4 tahapan yaitu: (1) plasmid yang menyandi gen target ditransformasi ke dalam sel bakteri, umumnya Escherichia coli, bakteri ini berpropagasi memproduksi sel yang 
mengandung plasmid dengan jumlah tinggi; (2) pemurnian atau purifikasi DNA plasmid; (3) DNA plasmid ditranfer ke sel eukariotik dan (4) vektor DNA plasmid menstimulasi respon imun. Tahapan 2 dan 3 merupakan tahapan yang biasa dilakukan dengan tingkat kegagalan yang minimal karena proses purifikasi, formulasi dan pengantaran (delivery) plasmid dilakukan tanpa modifikasi dan metodenya sudah banyak dikuasai para ahli. Lain halnya dengan tahap 1 dan 4 yang sangat sensitif untuk terjadinya perubahan vektor karena vektor plasmid DNA harus dirancang secara hati-hati dengan penambahan elemen fungsional yang penting untuk propagasi (replication origin) dan penanda seleksi (resisten antibiotik) dalam inang bakteri dan elemen yang penting untuk ekspresi tingkat tinggi dalam inang eukariotik (enhancer, promoter, terminator/sinyal poliadenilasi) dan mengaktivasi sistim imun (Williams et al., 2009).

Konstruksi plasmid sebagai bahan vaksin dilakukan melalui teknologi DNA. DNA target yang diisolasi dari bakteri, virus atau gen imunogenik disisipkan dalam plasmid. Untuk tujuan propagasi plasmid vaksin DNA, promoter, elemen replication origin/ORI, terminator dan gen penanda seleksi ditambahkan pula dalam konstruksi plasmid. Elemen lain yang harus dipersiapkan dalam konstruksi plasmid adalah enzim restriksi nuklease untuk memutus ikatan fosfodiesterase, enzim ligase, enzim yang akan memodifikasi sekuen 3' atau 5' terminus DNA dan enzim topoisomerase yang mampu mengubah konformasi ikatan kovalen DNA plasmid sirkuler menjadi super koil (Kumar et al., 2013). Setelah konstruksi, plasmid vaksin DNA ditransformasi ke dalam bakteri untuk ditumbuhkan dan menghasilkan sejumlah kopi plasmid vaksin. Plasmid vaksin DNA ini kemudian dipurifikasi dari bakteri, dipisahkan dari DNA bakteri dan komponen bakteri lainnya. Plasmid vaksin DNA hasil purifikasi ini dipakai sebagai vaksin (Mateen dan Irshad, 2011).

Vaksin DNA atau disebut juga vaksin genetik dibuat dari plasmid bakteri. Desain plasmid DNA vaksin melibatkan faktor biologi dan molekular yang penting untuk menentukan efikasi, keamanan dan produksi ekspresi dari vaksin DNA tersebut. Plasmid DNA vaksin pada umumnya mempunyai elemen fungsional untuk propagasi (replication origin), seleksi (misal resistensi antibiotik) pada sel inang bakteri, perangkat ekspresi (enhancer, promoter, terminator/sinyal poli adenil) dan kemampuan mengaktivasi imunitas melalui sintesis protein asing yang disandi gen target (Gambar 4). Variasi elemen dalam rancang vektor ini dapat mempengaruhi tingkat ekspresi, merubah lokalisasi intraseluler protein target (Ramanathan et al. 2001) dan memodifikasi respon imun (Zinckgraf \& Silbart, 2001). Menurut Williams et al. (2009) ekspresi antigen oleh plasmid DNA vaksin dipengaruhi oleh beberapa komponen antara lain promoter, mRNA leader, sekuen DNA yang disisipkan, terminator/poli adenilasi dan sekuen yang menyebabkan bentuk DNA helikal tidak stabil. Selain konstruksi vektor plasmid, kemampuan vaksin DNA dalam mengaktivasi respon imun jugaditentukan oleh transfeksi plasmid DNA dan penggunaan adjuvan (Abdulhaqq dan Weiner, 2008).

Replication origin/ORI yang dipakai dalam konstruksi DNA rekombinan untuk menghasilkan kopi replikon dengan jumlah yang tinggi antara lain Co1E1, pMB 1, R6K dan R1. ORI yang dipakai untuk menghasilkan kopi replikon merupakan derivat dari pMB1(contohnya pBR3, pUC 19) dan Co1E1 (contohnya pMM1, pMM7), berukuran sekitar 1 $\mathrm{kb}$ dan berinteraksi dengan RNAI/RNAll pada 
temperatur 30-42ํㅡ (Lin-Chao et al. 1992; Wong et al. 1982; Williams et al. 2009)

Vaksin DNA biasanya dirancang dengan promoter-promoter yang menginisiasi ekspresi antara lain promoter human cytomegalovirus (CMV)- $\beta$ actin (CAGG), promoter viral (SV40), promoter seluler human ubiquitin $\mathrm{C}(\mathrm{UbC})$ atau human elongation factor $1 \propto$ (EF-1 $\alpha)$. Vektor yang mengandung promoter CMV atau CAGG dilaporkan dapat memperbaiki imunogenisitas manusia (Williams et al. 2009). Promoter CMV ini dirancang dengan penambahan regio HTLV1R-U5 downstream yang terbukti meningkatkan ekspresi dan perbaikan respon imun seluler terhadap vaksin DNA HIV pada mencit dan primata bukan manusia (CMV/R promoter) (Barouch et al., 2005) dan respon imun humoral terhadap vaksin DNA influensa $\mathrm{H} 5$ hemaglutinin (Luke et al., 2009; Williams, 2008). Contoh plasmid vaksin DNA yang didesain dengan 2 promoter khimera SV40 dan CMV dapat dilihat pada Gambar 4.

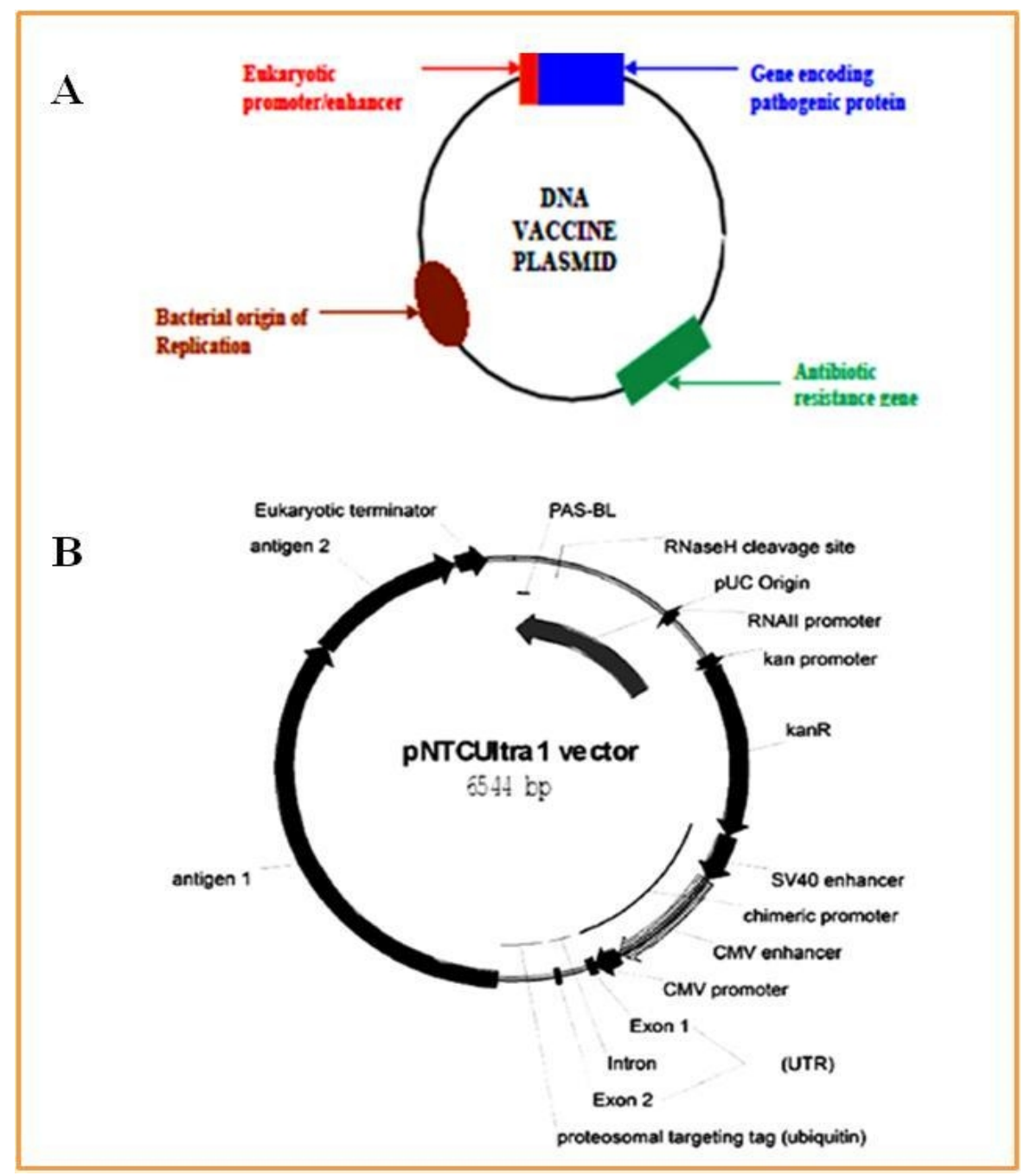

Gambar 4. A. Gambaran umum plasmid vaksin DNA. Plasmid vaksin DNA mengandung enhancer/promoter sebagai tempat melekatnya faktor transkripsi dan RNA polimerase; ORI untuk propagasi plasmid; gen resisten antibiotik, sebagai penanda seleksi dan gen target yang akan disisipi untuk menyandi protein (Rangarajan, 2002). B. Peta vektor pNTCUltra 1. Plasmid vaksin DNA pNTCUItra 1 dirancang dengan promoter khimera SV40-CMV, gen kanR, domain-domain PAS$\mathrm{BL}$, RNAll promoter, situs pemotongan RNase $\mathrm{H}$. Vektor ini membawa antigen fusi (antigen 1 dan 2) dengan $C$ terminus ubiquitin untuk degradasi proteosomal (Williams et al. 2009) 
Vaksin DNA pNTCUltra mempunyai perbaikan ekspresi dan imunogenisitas. Peningkatan ekspresi antigen dapat meningkatkan dosis dari antigen, peningkatan ini diharapkan dapat meningkatkan imunogenisitas dari produk antigen (Abdulhaqq \& Weiner, 2008). Selain desain promoter khimera, ekspresi antigen lebih meningkat jika plasmid vaksin DNA dirancang dengan adanya intron. Plasmid vaksin DNA pNTCUltra 1 mempunyai mRNA leader yang terletak pada intron antara ekson 1 dan 2. mRNA leader ini juga merupakan daerah untranslated region (UTR) yang pada daerah hilirnya mempunyai kodon inisiasi ATG sebelum ekson 2.

Sinyal poliadenilasi atau terminator transkripsi biasanya merupakan derivat yang diambil dari gen hormon pertumbuhan sapi, SV40 atau gen $\beta$ globin kelinci. Tujuan penambahan terminator atau poliadenilasi adalah mengurangi kemungkinan ekspresi peptida kripta dan menghindari perubahan ekspresi yang dimediasi oleh tertranskripnya mikro RNA yang tidak diinginkan (Williams et al., 2009).

\subsection{Imunogenisitas Vaksin DNA}

Imunogenisitas vaksin DNA ditentukan oleh komponen-komponen antara lain produk antigen, unmetylated $\mathrm{CpG}$, metilasi dam dan dcm serta RNA imunostimulator (Williams et al., 2009). Respon imun adaptif dapat diubah oleh antigen yang berperan pada kehadiran major histocompatibility complex (MHC) I dan MHC II. Penggunaan sikuen sinyal tissue plasminogen activator (TPA), endosomal targeting promoter dan beragam leader protein tag terbukti memperbaiki respon antibodi.

Sikuen imunostimulator seperti unmetylated $\mathrm{CpG}$ dari DNA bakteri atau plasmid menstimulasi respon imun T-lymphocyte (Th1) melalui toll like receptor 9 (TLR9) karena adanya gugus flanking dinucleotide, respon imun akan semakin meningkat dengan meningkatnya $\mathrm{CpG}$ dalam plasmid. Gen dcm menyandi DNA metilase yang memetilasi residu sitosin internal dengan sekuen pengenal 5'-CC*AGG-3' atau 5'CC*TGG-3'menjadi 5-methyl-cytosine (5mC). Gen dam menyandi dam metilase yang memetilasi adenosin internal dengan sequen pengenal $5^{\prime}-\mathrm{GA}^{*} \mathrm{TC}-3^{\prime}$ menjadi N6methyladenosine (Williams et al. 2009). Metilasi DNA plasmid pada situs dcm dan dam merubah pola ekspresi dalam promoter. Ekspresi dari promoter CMV lebih rendah pada DNA plasmid dengan gen unmetylated dibanding plasmid yang mempunyai $\mathrm{dam}^{+} \mathrm{dcm}^{+}$metylated pada daerah downstreamnya (Lai et al. 2008). DNA plasmid yang mempunyai $\mathrm{N}^{6} \quad$-metyladenosine meningkatkan induksi sitokin IL-12 pada mencit dibanding DNA kontrol unmetylated (Tsuchiya et al. 2005). Aktivasi ligan 5' triphosphate dsRNA (ligan untuk retinoic acid-inducible gene I/RIG-I) dan double-stranded RNA-dependent protein kinase (PKR) dapat mempengaruhi efek imunostimulasi DNA plasmid (Williams et al., 2009).

\subsection{Mekanisme aksi vaksin DNA}

Hal penting dari vaksin dan vaksinasi adalah reaksi (respon) dari pemakaian vaksin itu sendiri. Banyak faktor yang terlibat setelah virus, bakteri, peptida spesifik (vaksin = Antigen, Ag) masuk ke dalam tubuh. Ag yang masuk akan dikenal oleh reseptor sel $\mathrm{B}$ dan sel $\mathrm{T}$, yang mekanismenya melibatkan berbagai sel (antigen presenting cells/APC, MHC, CD4, CD8) dan begitu kompleks. Pemakaian kombinasi virus dalam vaksin (bivalent, polivalent) harus memperhatikan sifat virus sehingga dapat 
dihindari kompetisi $\mathrm{Ag}$ untuk menginduksi bersifat sebagai sel penyaji antigen (APC). kekebalan terhadap virus vaksin tersebut. Melalui jalur-jalur tertentu, baik jalur MHC I pada Respon kekebalan terjadi secara humoral dan sel CD8+ sel T atau jalur MHC II pada sel CD4+ seluler. Sel B dan $T$ yang aktif mensekresi Ab terhadap Ag yang masuk akan berbiak terus sel T, APC ini merangsang sistem imunitas tubuh (Gambar 5). Protein asing juga dapat (sel-sel memori) dan akan tetap aktif bila diberi langsung masuk ke dalam sel penyaji lainnya suntikan booster.

Mekanisme vaksin DNA dalam misalnya sel dendritik untuk menstimulasi respon imun.

merangsang sistem imun dapat diterangkan sebagai berikut. Plasmid yang disisipi DNA asing disuntikkan ke dalam jaringan, plasmid DNA ini akan bereplikasi secara otonom memproduksi protein asing atau antigen yang disandi oleh gen asing. Antigen dapat menstimulasi sel B untuk memproduksi antibodi terhadap antigen atau protein asing yang disandi oleh plasmid DNA. Sel yang mengandung antigen asing tersebut

Pengamatan studi berangkai untuk mengetahui kinerja vaksin DNA dalam menstimulasi sistem imun dimulai dengan cara mengimunisasi gen ke dalam sel otot secara intra muskular. Studi berangkai ini dapat mempelajari mekanisme aksi plasmid DNA dalam memproduksi antigen, perangkat imunologi yang terlibat dan peran sitokin dalam menstimulasi respon imun (Gambar 6).

A

$\mathrm{B}$

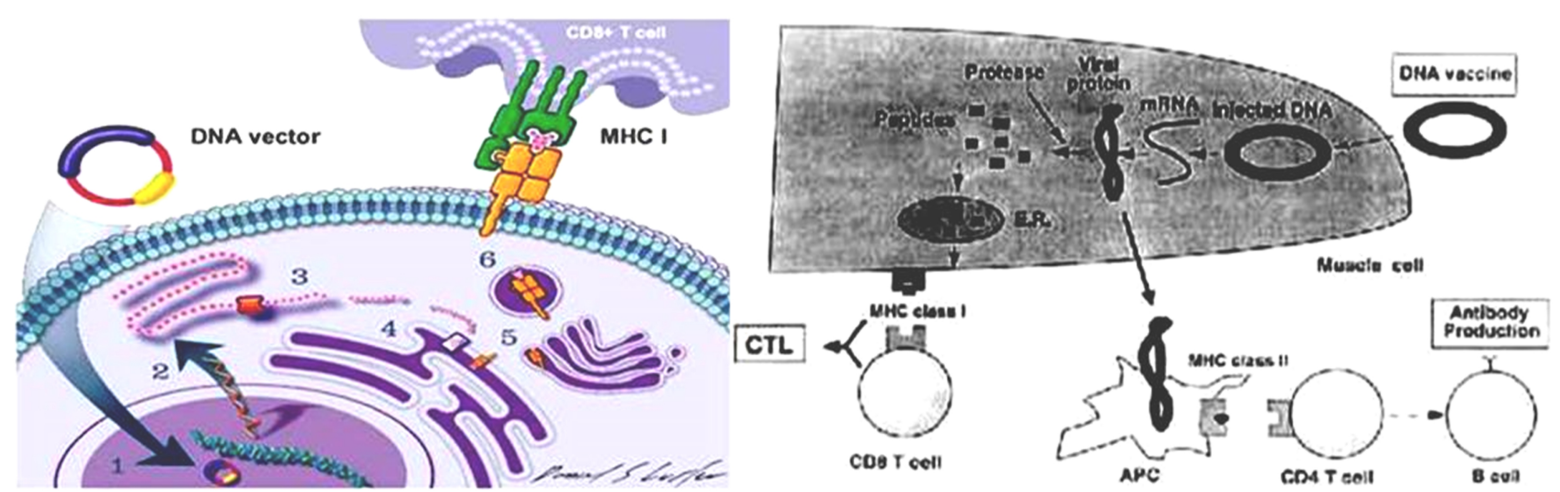

Gambar 5. Mekanisme aksi virus DNA. A. Vaksin DNA mempengaruhi respon imun yang dimediasi sel. Vektor plasmid DNA, sebagai vaksin, membawa informasi genetik yang menyandi antigen tumor atau patogen untuk menstimulasi respon imun melalui jalur MHC I. (1) vektor plasmid ditransformasi ke dalam inti sel, (2) plasmid mentranskripsi mRNA untai tunggal, (3) translasi mRNA menjadi antigen protein dan dilepas ke sitoplasma, (4) degradasi protein oleh proteosom menjadi peptida intraseluler, (5) peptida berikatan dengan molekul MHC kelas I, (6) komplek antigen peptida-MHC I ditransportasi ke permukaan sel dan komplek ini berikatan dengan sel T sitotoksik CD8+ untuk menginduksi respon imun (Mateen dan Irshad, 2011). B. Protein viral yang diekspresi DNA plasmid juga dapat berikatan dengan MHC kelas II APC untuk mengaktifasi CD4+ sel T. Aktifasi sel CD4+ ini menyebabkan sel B aktif memproduksi antibodi (Kumar et al. 2013). 


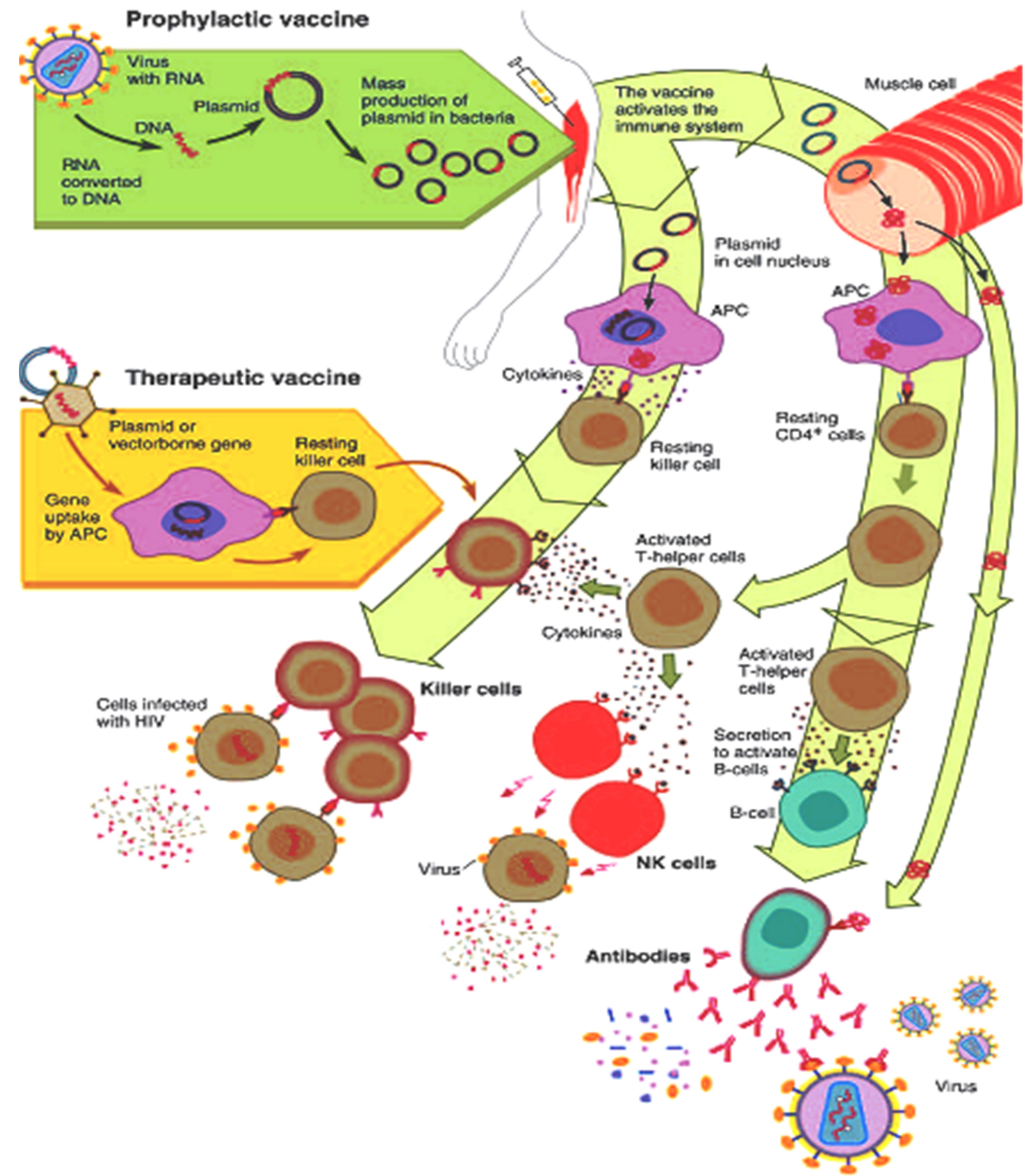

Gambar 6. Imunisasi dengan DNA Virus. Gen virus disisipkan pada plasmid bakteri. Plasmid DNA ini diberikan secara intra muskular pada kulit atau lapisan mukosa. Gen yang sama disisipkan pula ke dalam vektor (virus atau bakteri) yang digunakan sebagai vaksin DNA. Plasmid masuk ke inti sel, menginisiasi transkripsi dan translasi protein. Sekret protein yang dihasilkan ini menginduksi $T$ helper untuk menghasilkan peptida, yang digunakan untuk mengaktivasi sel B untuk menghasilkan antibodi yang melawan virus. APC juga terstimulasi mengeluarkan MHC untuk mengaktivasi sel NK melisis virus. Dalam terapi HIV, sel NK, walaupun hanya sedikit, mampu melisiskan protein asing HIV. Antigen dapat digunakan untuk menstimulasi respon imun baru atau sebagai boster untuk respon memori (Donnelly et al., 2005).

\subsection{Kelemahan dan keuntungan vaksin DNA}

Faktor utama yang dipikirkan untuk segi keamanan vaksin DNA adalah integrasinya sebagian atau seluruh genom plasmid ke dalam sel inang yang dapat memicu mutagenesis insersional atau mengaktivasi onkogen atau menginaktivasi gen supresor tumor. Salah satu cara untuk membatasi resiko ini adalah mengembangkan dan menggunakan plasmid atau molekul DNA yang tidak mempunyai gen untuk resistensi antibiotik dan elemen yang diperlukan untuk replikasi di dalam bakteri (Faurez et al., 2010). Food drug administration (FDA) merekomendasikan uji studi produk DNA 
baru atau kombinasi DNA dengan adjuvan pada hewan untuk megetahui laju mutasi (Mateen dan Irshad, 2011). Beberapa uji pra klinik pada binatang percobaan, integrasi vaksin DNA ke dalam kromosom hospes masih jauh lebih rendah dari pada mutasi spontan yang terjadi di alam (Glenting \& Wessel, 2005). Selain integrasi genom, vaksin DNA dapat menginduksi automunitas, toleransi imunologis dan reaksi alergi terhadap protein yang dihasilkan. Untuk membatasi resiko ini diperlukan pengetahuan dalam sistem pengantaran vaksin DNA dan ekspresinya di dalam sel (Mateen \& Irshad, 2011). Studi perkembangan autoimunitas pada mencit menunjukan bahwa autoimunitas sistemik bukan akibat vaksinisasi DNA dan studi awal pada manusia menunjukan setelah vaksinasi DNA tidak ditemukan peningkatan antinuklear dan antibodi anti DNA (MacGregor et al., 1998).

Vaksin DNA lebih aman dibanding live attenuated karena tidak menyebabkan infeksi patogenik secara in vivo. Studi lebih lanjut menunjukan bahwa pemberian vaksin DNA yang berkali kali tidak menghasilkan terbentuknya antibodi anti DNA. Kemampuan vaksin DNA untuk menstimulir respon imun yang kuat dari sel Th 1 CD4+ dan sel T sitotoksis CD8+, merupakan gambaran unik vaksin DNA yang dapat menginduksi respon imun seluler dan humoral.

Vaksin DNA selain dapat merangsang respon imun humoral melalui pembentukan antibodi, juga dapat merangsang imun selular melalui aktivasi sel $\mathrm{T}$ (cell-mediated response immune), sehingga dapat memberikan kekebalan terhadap mikroba patogen intraselular, misalnya terhadap Mycobacterium tuberculosis, virus, parasit, atau sel kanker melalui sel $\mathrm{T}$ pembunuh (killer $T$ cells) atau melalui efek sitotoksik. Keuntungan lainnya dari vaksin DNA adalah: (1) plasmid DNA mudah diproduksi dalam jumlah yang besar secara lebih ekonomis, dalam waktu yang lebih cepat dibandingkan dengan vaksin konvensional; (2) DNA sangat stabil, tahan terhadap perubahan suhu sehingga lebih mudah untuk disimpan dan didistribusikan; (3) sekuen DNA dapat diubah dengan mudah dalam laboratorium, sehingga vaksin DNA dapat disesuaikan dengan perubahan mikroorganisme patogen; (4) dapat direkayasa gabungan beberapa plasmid DNA yang mempunyai spektrum luas untuk beberapa epitop antigen dan (5) vaksin DNA terbukti dapat meningkatkan imunitas tubuh terhadap virus dan bakteri dalam waktu yang sangat lama (Radji, 2009).

\section{Vaksin Subunit Protein}

Epitop, bagian yang dikenali oleh antibodi, biasanya ditemukan pada salah satu atau beberapa protein yang berada di permukaan organisme patogen. Isolasi gen yang menyandi epitop (bagian imunogen dari protein) dan mengekspresikannya di dalam sel inang merupakan dasar dikembangkannya vaksin subunit rekombinan. Manfaat utama penggunaan epitop dari protein tunggal sebagai vaksin memungkinkan penginduksian imunitas yang tidak berefek samping dan menghindari respon imun yang diinduksi oleh bagian-bagian lain dari organisme patogen. Selain itu, vaksin subunit tidak bereplikasi dalam inang sehingga tidak patogen dan lebih aman namun demikian penggunaan vaksin ini masih memerlukan kajian dosis dan penggunaan adjuvan (Hansson et al. 2000).

Strategi rekombinan yang dikerjakan untuk memproduksi vaksin subunit protein antara lain (1) sintesis fragmen gen yang akan diekspresikan, (2) pemilihan sub fragmen gen yang memiliki bagian imunogen, (3) penggunaan protein fusi untuk memperbaiki imunogenitas, (4) 
rekayasa protein untuk memperbaiki solubilitas dan stabilitasnya dan (5) penggunaan adjuvan untuk meningkatkan imunogen subunit rekombinan (Liljeqvist dan Stahl, 1999).

\subsection{Konstruksi Gen dan Sistem Ekspresi Protein}

Pemilihan fragmen DNA dan sintesis fragmen gen yang akan dsekresikan merupakan tahap penting dalam konstruksi gen dalam plasmid. Dalam konstruksi gen, dibutuhkan seleksi optimal pada daerah atau fragmen gen yang diperkirakan dapat menimbulkan respon imun kuat, meminimalis panjang DNA untuk menghindari kegagalan insersi ke dalam vektor dan membuang sekuen yang menyandi protein toksik. Selain itu, dalam mengkonstruksi gen perlu diperhitungkan pula pemilihan vektor dan sel inang agar gen dapat mengekspresikan protein yang diinginkan serta pembentukan badan inklusi (yang sering ditemukan pada ekspresi protein transmembran) untuk melindungi protein dari degradasi proteolitik. Strategi konstruksi gen pada prinsipnya serupa dengan konstruksi plasmid pada vaksin DNA yaitu melalui tehnologi rekombinan DNA. Secara rinci, pengklonaan gen meliputi empat tahap utama, yaitu konstruksi DNA (Deoxyribonucleic acid) rekombinan, tranformasi, seleksi sel klona, pengisolasian DNA rekombinan dan pemilihan sel inang yang digunakan untuk wahana perbanyakan klon dan ekspresi (Strachan \& Read, 1999). Sumber DNA, vektor dan sel inang merupakan komponen penting dalam pengklonaan gen (Gambar 7).

Sumber DNA berasal dari DNA kromosom (hasil isolasi inti sel atau organel lain dalam sel seperti mitokondria dan kloroplas) ataupun complementary DNA (cDNA) yang diperoleh dari penyalinan mRNA dengan batuan enzim reverse transcriptase (Watson et. al., 1992; Snustad \& Simmons 2003). Umumnya cDNA digunakan untuk keperluan ekspresi gen eukariot dalam sel prokariota, cDNA dapat disintesis dari mRNA dengan tehnik reverse transcription polymerase chain reaction (RTPCR) (Nicholl, 2002; Davis et al., 1994).

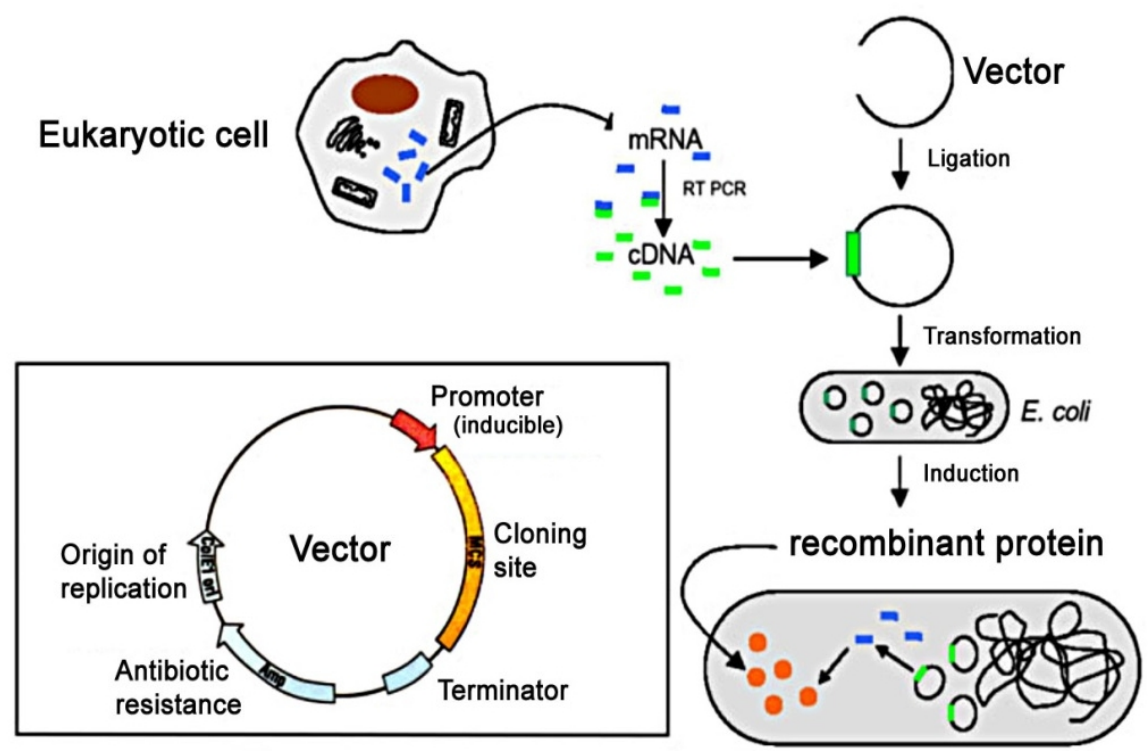

Gambar 7. Prinsip dasar produksi protein rekombinan. Konstruksi DNA rekombinan melibatkan perangkat DNA target, vektor, enzim restriksi dan ligase. Hasil konstruksi ditransformasi ke dalam sel inang (misal bakteri E coli) untuk perbanyakan vektor pada medium agar. Vektor (plasmid) yang mengandung DNA rekombinan diisolasi, ditransformasi ke dalam sel kompeten ekspresi, dibiakkan dalam medium kultur, selanjutnya protein rekombinan yang terekspresi diisolasi dan dimurnikan (purifikasi). 
Metode kloning DNA melibatkan ligasi suatu urutan/sekuens tertentu ke dalam vektor. Vektor adalah molekul yang dapat membawa (media transportasi) DNA asing ke dalam sel inang (Pierce 2005). Vektor dapat berupa plasmid, bakteriofaga, fagemid, kosmid, yeast artificial chromosomes (YACs), dan bacterial artificial chromosomes (BACs). Vektor yang umum digunakan untuk sel bakteri adalah plasmid. Plasmid merupakan vektor yang paling banyak dipelajari karena memiliki banyak informasi genetik untuk manipulasi dan konstruksi vektor. Vektor ekspresi merupakan vektor yang digunakan dalam ekspresi gen, vektor ini harus memiliki elemen genetik yang mengontrol proses transkripsi, translasi dan sekresi protein rekombinan yang diekspresikan oleh sel inang. Komponen-komponen genetik penting tersebut adalah origin of replication (ori), promoter transkripsional, penanda/marker resistensi antibiotik, translation initiation region (TIR), ribosomal binding site (RBS) dan terminator (Sorensen \& Mortenson, 2005).

Ekspresi protein adalah proses pembentukan protein yang dimulai dari penyandian informasi genetik DNA, ditranskripsikan menjadi mRNA dan ditranslasikan oleh ribosom menjadi struktur protein. Sistem ekspresi bakterial merupakan sistem ekspresi prokariota yang paling umum digunakan untuk menghasilkan protein rekombinan. Pada sistem ekspresi prokariota, operon merupakan unit transkripsi, yang terdiri atas gen struktural dan gen regulator (yaitu promoter, operator dan terminator). Operon lac terdiri dari satu gen regulator (gen lacl) dan tiga gen struktural yaitu gen lacZ, lacY dan lacA. Gen lac $Z$ menyandi $\beta$-galaktosidase yang berfungsi menghidrolisis laktosa menjadi monosakarida (galaktosa dan glukosa). Gen lacY menyandi enzim permease yang berfungsi meningkatkan permeabilitas sel sehingga laktosa dapat diangkut dari luar ke dalam sel sedang gen lacA menyandi trans-asetilase.

Organisme yang dipakai pada sistem ekspresi bakterial antara lain Escherichia coli, Lactoccocus lactis, Pseudomonas dan Bacillus. Sistem ekspresi bakterial yang paling sering digunakan dalam ekspresi adalah E. coli karena bakteri ini mudah untuk dimanipulasi, tidak mahal, cepat menghasilkan protein rekombinan, tingkat ekspresinya tinggi dan sistem ekspresinya banyak tersedia (Sorensen dan Mortensen, 2005; Young et. al., 2012). Namun kekurangan sistem ekspresi $E$. coli antara lain protein tidak dapat dimodifikasi pasca translasi, protein yang diekspresi secara berlebihan dapat teragregasi dalam badan inklusi dan tidak optimal untuk ekspresi protein mamalia (Hannig dan Makrides, 1998). Untuk mengatasi kekurangan dalam hal ekspresi ini, para peneliti mengeksplorasi dengan menggunakan beberapa galur E. coli alternatif, temperatur yang berbeda, induktor atau penanda fusi.

Sel inang yang sering digunakan dalam ekspresi protein adalah BL21 dan derivatnya karena defisiensi gen protease untuk enzim lon dan ompT protease. B834 merupakan strain yang produk proteinnya ditandai dengan $35 \mathrm{~S}$ methionine atau selenomethionine. BLR adalah derivat dari $\mathrm{BL} 21$ recA yang mempunyai kemampuan menstabilisasi plasmid yang mengandung sekuuen repetitif. AD494 dan BL21 $\operatorname{trx} B$ yang dilengkapi gen penyandi thioredoxin reductase, enzim yang memfasilitasi pembentukan ikatan disulfida protein dalam $E$ coli.

E. coli galur BL21 merupakan inang yang telah terbukti sangat baik dalam aplikasi ekspresi protein rekombinan. BL21 merupakan galur E. coli yang kuat, mampu tumbuh dengan 
baik dalam medium yang minimal namun bersifat non patogenik. Galur BL21 tidak memiliki protease yang disandi oleh gen Lon, enzim ini mengkatalis pemotongan endoproteolitik protein rekombinan dalam sel. Selain itu, galur ini juga membawa delesi gen OmpT yang menyandi outer membraneprotease sehingga dapat mereduksi degradasi protein heterolog yang dihasilkan selama proses ekspresi. BL21 dapat diinduksi dengan penambahan IPTG. Induktor IPTG akan berikatan dengan lac repressor untuk mengurangi affinitas ikatan RNA polymerase $E$ coli ke lac operator dan memungkinkan ikatan T7 RNA polymerase ke promoter lacUV5 plasmid sehingga gen target dapat bertranskripsi (Sorensen \& Mortenson, 2005; Studier et al., 1986).

Ekspresi protein ditentukan oleh jumlah mRNA, yang pembentukannya terutama dipengaruhi oleh afinitas RNA polimerase dan promoter. Ekspresi protein terjadi karena pengaruh promoter yang berada di hulu plasmid rekombinan kloning. Promoter-promoter yang digunakan dalam sistem ekspresi bakteri antara lain promoter lac, tac, PL, T7 dan Ara-BAD, dimana aktivitas promoter-promoter tersebut diinduksi dengan cara berbeda. Promoter lac, tac dan T7 dapat diinduksi dengan penambahan substrat IPTG (isopropil $\beta$-D-thiogalactosida). Promotor Ara-BAD dapat diinduksi dengan penambahan I-arabinose (Sorensen \& Mortenson, 2005).

\subsection{Penanda Fusi dan Purifikasi Protein Rekombinan}

Protein rekombinan umumnya dilengkapi dengan fusi polipeptida, disebut juga tag atau pelabelan affinitas, tag ini memfasilitasi purifikasi, deteksi, stabilisasi dan kelarutan protein target. Pemilihan sistem purifikasi tergantung pada proteinnya sendiri dan aplikasi selanjutnya. Untuk aplikasi, tag berukuran kecil dalam protein rekombinan tidak perlu dihilangkan karena tag-tag ini tidak bersifat imunogenik dan dapat digunakan langsung dalam produksi antibodi. Namun lokasi dan komposisi asam amino mempengaruhi aktivitas biologi dan struktur tersier dari tag-tag berukuran kecil (Bucher et al., 2002). Pemilihan protein fusi yang tepat dapat meningkatkan kelarutan (solubilitas) protein rekombinan di dalam sitoplasma karena tag atau protein fusi ini mempunyai afinitas terhadap matriks yang digunakan dalam purifikasi, selain itu tag atau pelabelan dengan protein fusi memungkinkan protein rekombinan dapat dimurnikan lagi karena tag protein fusi mempunyai situs restriksi untuk protease. Beberapa tag telah dikembangkan dengan situs pengenalan protease untuk pemotongan protein fusi, yaitu His-tag (purifikasi pada Ni NTA), fusi glutathione S-transferase/GST (afinitas terhadap glutathione S-transferase), fusi maltose binding protein/MBP (afinitas pada amylase-sepharose), fusi thioredoxin (Trx) (purifikasi pada Ni NTA sepharose) dan fusi NusA (purifikasi pada $\mathrm{Ni}$ NTA sepharose) (La Vallie, 1995; Young et al., 2012).

Poly-histidine tags (His-tags), tersusun atas 2 hingga 10 residu histidin, merupakan tag affinitas yang paling umum digunakan untuk purifikasi. Penambahan residu histidin ini dapat di N- atau C- terminus dari protein rekombinan. His-tags mempunyai kemampuan untuk berikatan dengan matriks ion metal yang immobil seperti $\mathrm{Zn}^{2+}, \mathrm{Cu}^{2+}, \mathrm{Ni}^{2+}$, dan $\mathrm{Co}^{2+}$. His-tag pada protein rekombinan dapat berinteraksi dengan suatu metal-chelate resin seperti $\mathrm{Ni}^{2+}$-NTA pada matriks agarosa. Nitrilotriacetic acid (NTA), merupakan transition metal chelate yang umum digunakan untuk purifikasi protein rekombinan. 
NTA membentuk tentradentate chelate dengan ion $\mathrm{Ni}^{2+}$, atau transition metal ion lain (e.g. $\mathrm{Co}^{2+}$, $\left.\mathrm{Cu}^{2+}, \mathrm{Zn}^{2+}\right)$ dengan ligan berjumlah 6. NTA menempati 4 dari 6 ligand bindang sites dari ion metal dan sekuen $\mathrm{His}_{6}$ dari protein menempati 2 ligand binding sites, imidazole dapat berikatan dengan histidin membentuk ikatan dengan komplek Ni NTA (Gambar 8) (Hochuli et al., 1987).

Efisiensi purifikasi sangat tergantung pada panjang poly-histidine dan pelarut. Purifikasi protein dengan tag-His 6 dapat efisien dibawah kondisi denaturasi, protein ini dapat berikatan dengan matrik Ni NTA dibawah kondisi alami dengan menggunakan buffer tinggi atau rendah garam. Setelah binding, protein target dapat terelusi efektif oleh imidazol dengan konsentrasi 20 sampai $250 \mathrm{mM}$ (Hefti et al., 2001; Janknecht et al., 1991).

IMAC dengan penanda His telah secara luas digunakan dalam teknologi ekspresi dan purifikasi protein rekombinan. Secara komersial vektor yang memiliki penanda His (protein fusi) telah banyak tersedia. Jumlah His yang sedikit dimaksudkan agar tidak mengganggu sisi aktif protein target pada fungsi hayati. IMAC merupakan teknik purifikasi terpopuler dalam purifikasi protein rekombinan dari mulai skala penapisan proteomik sampai skala produksi biofarmasetikal (Charlton \& Zachariou, 2008). Penambahan label polyHis ternyata dapat mempengaruhi fungsi dari protein target atau menghasilkan ikatan yang lemah untuk memilih matriks yang disebabkan perubahan muatan protein, namun kondisi ini dapat dihindari dengan mengubah lokasi label polyHis (misal pelabelan ditempatkan pada $\mathrm{N}$ atau C-terminal). Selain itu, IMAC tidak boleh dilakukan pada purifikasi protein dengan inti logam karena logam dapat terabsorbsi pada kolom, purifikasi juga tidak boleh dilakukan pada kondisi anaerobik karena $\mathrm{Ni}^{2+}$-NTA akan tereduksi sehingga menjadi tidak efektif pada kondisi lingkungan anaerobik. Beberapa faktor yang menyebabkan variabilitas deteksi pada protein rekombinan yang mempunyai His-tags yaitu kemampuan His-tags terhadap antibodi, lokasi His-tags pada protein, kemurnian protein, konstanta dissosiasi antibodi dan panjang His-tags (Debeljak et al.,1995).

\subsection{Mekanisme Aksi Subunit Protein dan Adjuvan dalam Respon Imun}

Vaksin subunit yang berupa peptida atau protein rekombinan secara alami merupakan vaksin yang kurang imunogen ketika diberikan sendiri sehinggan diperlukan suatu adjuvan untuk meningkatkan respon imun. Adjuvan yang beredar dan direkomendasikan oleh FDA (United States Food and Drug Administration) untuk manusia ada 2 jenis, keduanya merupakan garam alumunium, yaitu alumunium hidroksida dan alumunium fosfat (Petrovsky \& Aguilar, 2004), sedangkan adjuvan imunogenik yang paling sering digunakan dalam penelitian eksperimental adalah Freund adjuvan (Billiau \& Matthys, 2001). Adjuvan Freund merupakan emulsi air-minyak mineral tanpa tambahan mycobacteria yang dimatikan dengan pemanasan (incomplete freund adjuvant, IFA) atau dengan tambahan mycobacteria yang dimatikan dengan pemanasan (complete freund adjuvant, CFA).

Secara umum, adjuvan dan antigen dapat menstimulasi respon imun melalui 4 mekanisme yaitu (1) pengaruh depot adjuvan dan antigen di APC, (2) aktivasi pattern recognition receptor (PRR), (3) aktivasi inflamasoma dan (4) hadirnya MHC (Gambar 8). 


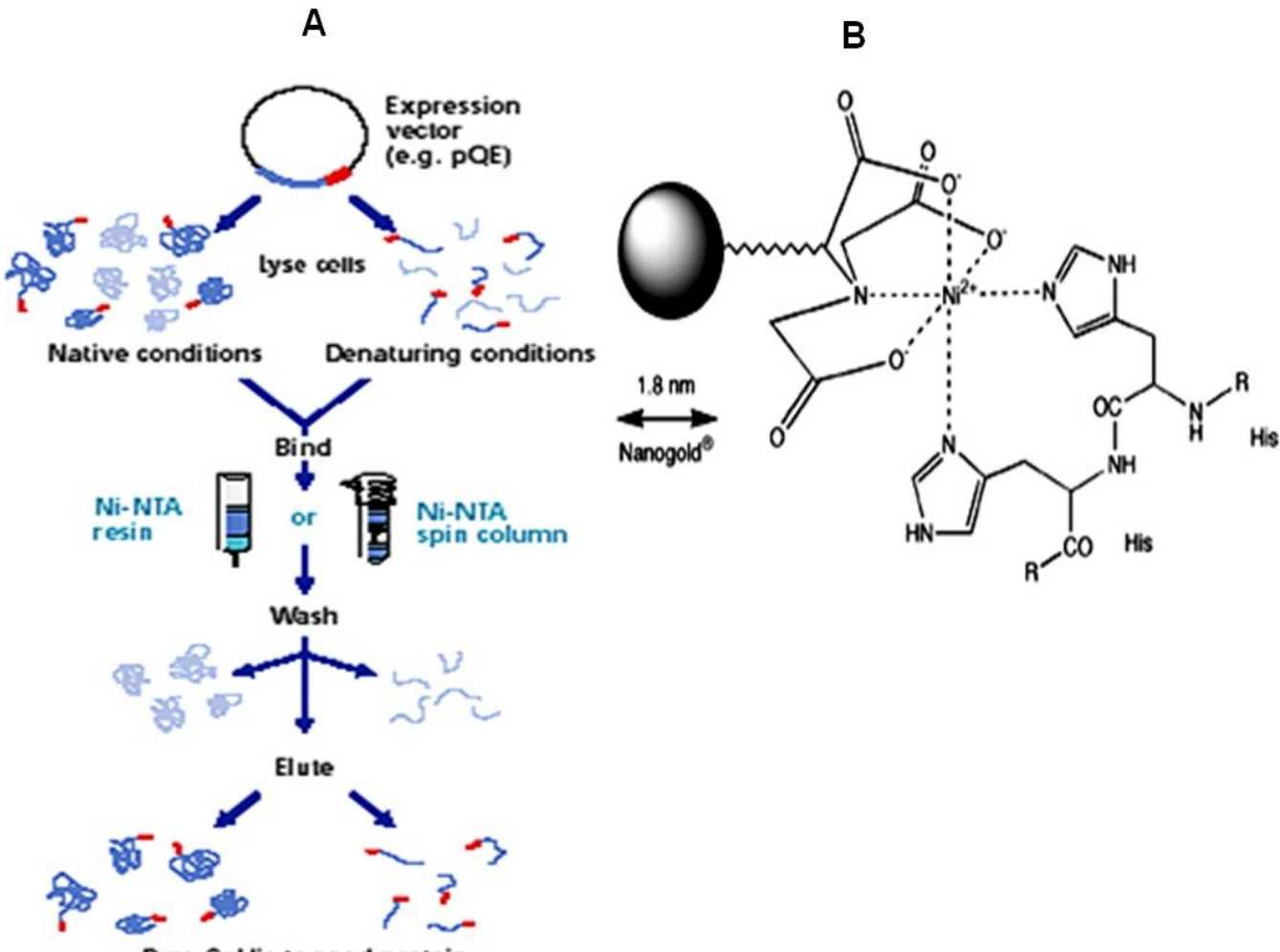

Pure 6xHis-tagged protein

Gambar 8. A. Purifikasi protein dengan sistem purifikasi Ni NTA. Protein rekombinan dapat dipurifikasi dari total protein dalam kondisi alami (native) atau denaturasi, protein berikatan dengan Ni NTA agarosa. B. Struktur kimiawi Ni NTA. Setiap Ni NTA menangkap 2 tag His protein pada ligand binding site.

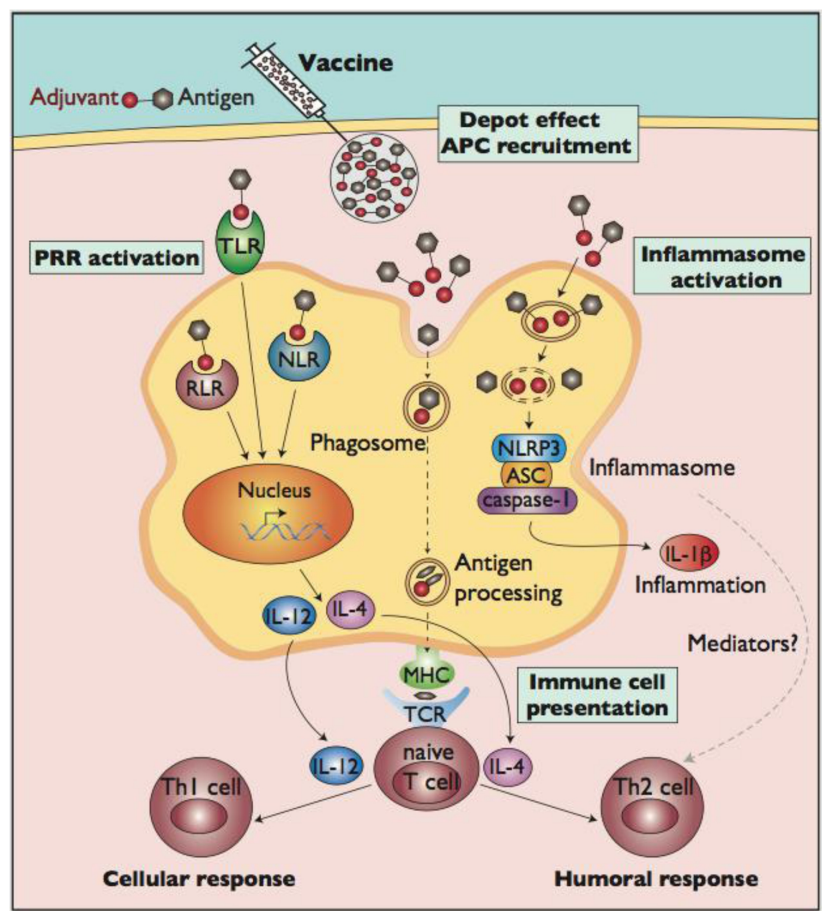

Gambar 8. Mekanisme adjuvan dan antigen dalam menstimulasi respon imun. Adjuvan dan antigen menstimulasi respon imun seluler dan humoral dapat melalui 4 jalur yaitu depotasi APC, aktivasi PRR, aktivasi inflamasoma dan aktivasi sel T helper. NLR-NOD like receptors-nucleotide binding oligomerization domain; RLR-RIG like receptors-retinoic acid inducible gene 1-RNA viruses; ASCApoptosis associated speck like protein containing a caspase recruitment domain; Th T helper. 
Setelah diinjeksikan, adjuvan dan antigen membentuk agregat-agregat mikromolekular, depot adjuvan dan antigen ini dikenali dan berikatan dengan reseptor permukaan (PRR) APC, reseptor TLR (toll-like receptor) dan NLR (nucleotide binding oligomerization domain/NOD like receptor) dan RLR (retinoid acid inducible gene 1-RNA virus/RIG like receptor) yang akan menginduksi inti APC menyandi dan mengekspresikan sitokin IL-12 dan IL-4. Depot adjuvan dan antigen di permukaan APC dapat difagositosis dan saat berada di fagosoma, antigen mengalami proses yang dikeluarkan sebagai molekul MHC. Adjuvan dan antigen di permukaan APC dapat menimbulkan reaksi inflamasi (biasanya reaksi ini terjadi jika menggunakan alumunium sebagai adjuvan), reaksi ini akan mengaktivasi caspase untuk mengekspresikan sitokin IL-18, IL-33 dan IL-1y. Molekul MHC berikatan dengan $\mathrm{T}$ cell receptor (TCR) dari sel T Helper (Th). Sitokin IL12 mengaktivasi sel Th1 menginduksi respon imun seluler makrofag, CTL dan sel NK untuk menghasilkan antibodi IgG, sementara sitokin IL4 mengaktivasi sel Th2 menginduksi respon imun humoral sel B untuk mengekspresikan antibodi IgA dan IgE (Reed et al., 2013; Vogel, 2000).

Pemberian adjuvan dengan suatu antigen dapat meningkatkan respon imun spesifik antigen tersebut tanpa mempunyai aktivitas antigenik spesifik pada adjuvannya sendiri (O’Hagan, 2007). Adjuvan meningkatkan potensi antigenik dari peptida rekombinan atau sintetik dengan cara menstabilkan konformasi epitop antigen. Adjuvan terdeposit pada situs inokulasi dengan melepas antigen secara perlahan dan membantu antigen berikatan dengan APC melalui pembentukan agregatagregat multimolekular atau membantu pengikatan antigen ke reseptor permukaan APC Adjuvan meningkatkan ukuran antigen terlarut untuk dapat dikenali oleh makrofag dan fagosit sebagai partikel yang berukuran hampir $10 \mu \mathrm{m}$ (Eldridge et al. 1991). Stimulasi respon imun oleh adjuvan dimodulasi oleh rute, waktu, formulasi dan dosis adjuvan, konstruksi antigen, hospes, variasi genetik intraspesies dan status imun dari hospes (Edelman, 2000).Tidak semua adjuvan efektif untuk beberapa antigen. Adjuvantisitas suatu adjuvan tergantung dari kompatibel atau inkompatibel kombinasi antigenadjuvan.

\subsection{Kelemahan dan keuntungan vaksin subunit protein}

Vaksin subunit protein semakin dikembangkan karena diyakini lebih potensial, lebih aman dan karakteristiknya lebih mudah diketahui. Untuk pertama kali, vaksin subunit diambil dari antigen permukaan yang termurnikan dari virus hepatitis $B$ yang diekspresikan oleh ragi (Andre, 1990). Sebelumnya, vaksin subunit Bordetella pertussis (vaksin aseluler) pertama kali diaplikasikan untuk studi struktur dan fungsi dalam produksi toksin pertussis (Pizza et al., 1989). Sampai saat ini, pencarian kandidat vaksin subunit terus dilakukan untuk mendapatkan vaksin yang mampu melawan mikroorganisme patogen pada manusia termasuk kandidat protein dari bakteri Staphylococcus aureus, Streptococcus pneumoniae, Neisseria meningitidis dan Mycobacterium tuberculosis (Unnikrishnan et al., 2012).

Vaksin subunit protein dapat berupa protein yang disekresikan atau protein permukaan yang termurnikan, komplek protein polisakarida, protein yang membawa tag atau protein fusi dan protein khimera (Unnikrishnan et 
al., 2012). Keuntungan vaksin subunit protein antara lain produk subunitnya terkarakterisasi dengan baik, antigen yang dipakai lebih potensial dan lebih aman. Kelemahan vaksin subunit antara lain biasanya vaksin ini membutuhkan adjuvan untuk menstimulasi respon imun, proses perancangannya lebih komplek dan ada beberapa yang tidak dapat dilakukan modifikasi subunit paska translasi (Unnikrishnan et al., 2012).

\section{Simpulan}

Teknologi DNA rekombinan dapat digunakan untuk mendesain vaksin DNA rekombinan dan subunit protein. Pada prinsipnya, vaksin rekombinan ini dibuat dengan tehnik pengklonaan menggunakan vektor, DNA target, enzim restriksi dan ligasi serta sel inang untuk perbanyakan klona dan ekspresi. DNA rekombinan yang dihasilkan dapat dijadikan sebagai vaksin DNA atau diekspresikan dan dipurifikasi proteinnya untuk dijadikan vaksin subunit protein.

\section{Daftar Pustaka}

Abdulhaqq SA, Weiner DB. 2008. DNA vaccines: developing new strategies to enhance immune responses. Immunol Res. 42:219-232.

Andre FE. 1990. Overview of a 5-year clinical experience with a yeast-derived hepatitis B vaccine. Vaccine. 8(Suppl.): S74-S78 discussion S79-80.

Barouch DH. 2005. A human T-cell leukemia virus type 1 regulatory element enhances the immunogenicity of human immunodeficiency virus type 1 DNA vaccines in mice and nonhuman primates.

$J$ Virol. 79:8828-34.
Billiau A, Matthys P. 2001. Modes of action of Freund's adjuvants in experimental models of autoimmune diseases. $J$. Leukoc. Biol. 70: 849-860.

Brooker RJ. 2005. Genetics: Analysis and principles. Second Edition. McGraw-Hill Companies, Inc., Boston. xxii + 842 hlm.

Bucher MH, Evdokimov AG, Waugh DS. 2002. Differential effects of short affinity tags on the crystallization of Pyrococcus furiosus maltodextrin-binding protein. Biol Cryst. 58:392-397.

Davis LG, Kuehl WM, Battey JF. 1994. Basic methods in molecular biology. Second Edition. Appleton \& Lange, Norwalk. xiii + $763 \mathrm{hlm}$.

Debeljak N, Feldman L, Davis KL, Komel R, Sytkowski AJ. 2006. Variability in the Immuno-detection of His-tagged Recombinant Proteins. Anal Biochem. 359(2): 216-223.

Donnelly JJ, Wahren B, Liu MA. 2005. DNA Vaccines: Progress and Challenges. Immunology. 175: 633-639.

Edelman R. 2000. An Overview of Adjuvant Use. Dalam : Methods in molecular medicine . Vaccine adjuvants: preparation methods and research protocols / edited by Derek T. O'Hagan. Humana Press Inc. Totowa New Jersey. 1-27.

Eldridge JH, Staas JK, Meulbroek JA, Tice TR, Gilley RM. 1991. Biodegradable and biocompatible poly (DL-lactide-coglycolide) microspheres as an adjuvant for staphylococcal enterotoxin $B$ toxoid which enhances the level of toxinneutralizing antibodies. Infect Immun. 59(9):2978-86.

Faurez F, Dory D, Le Moigne V, Gravier R, Jestin A. 2010. Biosafety of DNA vaccines: New generation of DNA vectors and 
current knowledge on the fate of plasmids after injection. Vaccine. 28: 3888-3895

Griffiths AJF, Gelbart WM, Miller JH, Lewontin RC. 1999. Modern genetic analysis. W.H. Freeman Company, New York. xvi + 675 hlm.

Glenting J, Wessel S. 2005. Ensuring safety of DNA vaccines. Microbial Cell Factorie. 4:26.

Hannig G, Makrides SC. 1998. Strategies for optimizing heterologous protein expression in Escherichia coli. Trends Biotechnol.16:54-60.

Hefti MH, Van Vugt-Van der Toorn CJG, Dixon, R., Vervoort, J. 2001. A Novel Purification Method for Histidine-Tagged Proteins Containing a Thrombin Cleavage Site. Anal Biochem. 295:180-185.

Hochuli E, Dobeli A, Schacher A. 1987. New metal chelate adsorbent selective for proteins and peptides containing neighbouring histidine residues. $J$. Chromatogr. 411:177Y184.

Invitrogen. 2010. Champion ${ }^{\mathrm{TM}}$ pET Directional TOPO expression kits. Cat. No K100-01 Invitrogen Corp. California. xiii $+60 \mathrm{hlm}$.

Janknecht R, de Martynoff G, Lou J, Hipskind, R., Nordheim, A., Stunnenberg, H.G. 1991. Rapid and efficient purification of native histidine-tagged protein expressed by recombinant vaccina virus. Proc Natl Acad Sci. 88:8972-8976.

Kumar U, Kumar S, Varghese S, Chamoli R, Barthwal P. 2013. DNA vaccine: a modern biotechnological approach towards human welfare and clinical trials. Int $J$ of Research in Biomedicine and Biotechnology 2013; 3(1): 17-20.

Lai YF, Tseng YJ, Yang FY, Au LC. 2008. Mammalian cis-reporting plasmid may alter activities due to the derivation of host Escherichia coli strains. Anal Biochem. 376:103-7.

La Vallie ER, Mc Coy JM. 1995. Gene fusion expression systems in Escherichia coli. Current Opinion Biotechnology. 6:501-506

Liljeqvist S, Stahl S. 1999. Production of recombinant subunit vaccines: protein immuno- gens, live delivery systems and nucleic acid vaccines. J Biotech. 73: 1-33.

Lin-Chao S, Chen W, Wong T. 1992. High copy number of the pUC plasmid results from a Rom/Ropsuppressible point mutation in RNAll. Mol Micro. 6:3385-93.

Luke J, Carnes AE, Hodgson CP, Williams JA. 2009. Improved antibiotic-free DNA vaccine vectors utilizing a novel RNA based plasmid selection system. Vaccine. 27(46):6454-9.

Mac Gregor RR, Boyer JD, Ugen KE, Lacy KE, Gluckman SJ, Bagarazzi ML, Chattergoon MA, Bain Y, Higgins TJ, Ciccarell RB, Coney LR, Ginsberg RS, Weiner DB. 1998. First human trial of a DNA-based vaccine for treatment of human immunodeficiency virus type 1 infection: safety and host response. J Infect Dis. 1998; 178(1):92-100 .

Mateen I, Irshad, S. 2011. A Review on DNA Vaccines. J Health Sciences. 1(1):1-7.

Nascimento, IP, Leite LCC. 2012. Recombinant vaccines and the development of new vaccine strategies. Braz J Med Biol Res. 45(12):1102-1111.

Nicholl DST. 2002. An introduction to genetic engineering. Second Edition. Cambridge University Press, New York. 2002: xi + 292 hlm. 
O'Hagan. 2007. New Generation Vaccine Adjuvants. Encyclopedia Of Life Sciences. John Wiley \& Sons, Ltd. www.els.net:1-7.

Pizza M, Covacci A, Bartoloni A, Perugini M, Nencioni L, De Magistris MT, Villa L, Nucci D, Manetti R, Bugnoli M. 1989. Mutants of pertussis toxin suitable for vaccine development. Science. 246:497-500.

Petrovsky N, Aguilar JC. 2004. Vaccine adjuvants: Current state and future trends. Immunol Cell Biol. 82(5):488-96

Radji M. 2011. Rekayasa Genetika; Pengantar untuk Profesi Kesehatan.Sagung Seto: Jakarta.

Ramanathan MP, Ayyavoo V, Weiner DB. 2001. Choice of expression vector alters the localization of a human cellular protein. DNA Cell Biol. 20:101-5.

Rangarajan PN. 2002. DNA Vaccines. Resonance. 25-34.

Reed SG, Orr MT, Fox CB. 2013. Key roles of adjuvants in modern vaccines Nature Medicine. 19:1597-1608.

Snustad DP, Simmons MJ. 2003. Principles of genetics. Third Edition. John Wiley \& Sons, Inc. NY. xix + $840 \mathrm{hlm}$.

Sorensen H, Mortensen K. 2005. Advanced genetic strategies for recombinant protein expression in Escherichia coli. J Biotech. 115:113-128.

Strachan T, Read AP. 1999. Human molecular genetics 2. Second Edition. A John Wiley \& Sons, Inc., New York. xxiii + 576 hlm.

Studier FW, Moffatt BA. 1986. Use of bacteriophage T7 RNA polymerase to direct selective high level expression of cloned genes. J Mol Biol. 189:113-130.

Tsuchiya $\mathrm{H}$, Matsuda $\mathrm{T}$, Harashima $\mathrm{H}$, Kamiya H. 2005. Cytokine induction by a bacterial
DNA-specific modified base. Biochem Biophys Res Commun. 326:777-81.

Unnikrishnan M, Rappuoli R, Serruto D. 2012. Recombinant bacterial vaccines. Current Opinion in Immunology. 24:337-342.

Vogel FR. 2000. Improving Vaccine Performance with Adjuvants. Clinical Infectious Diseases. 30(Suppl 3):S266-70.

Ward WW, Swiatek G. 2009. Protein purification. Current Analytical Chemistry. 5:2 :1-21

Watson JD, Gilman M, Witkowski J, Zoller M. 1992. Recombinant DNA. Second Edition. W.H. Freeman and Company, New York. xiv $+626 \mathrm{hlm}$.

Williams JA, Carnesa AE, Hodgson CP. 2009. Plasmid DNA Vaccine vector design: impact on efficacy, safety and upstream production.Biotechnol Adv. 27(4): 353370.

Wolff JA, Malone RW, Williams P, Chong W, Acsadi G, Jani A. 1990. Direct gene transfer into mouse muscle in vivo. Science. 247: 1465-1468.

Wolff JA, Ludtke JJ, Acsadi G, Williams P, Jani A. 1992. Longterm persistence of plasmid DNA and foreign gene expression in mouse muscle. Hum. Mol. Gen. 1: 363369.

Wong DWS. 2007. The ABC of gene cloning. International Thomson Publishing, New York. 2007: xiv + 213 hlm.

Young CA, Britton ZT, Robinson AS. 2012. Recombinant protein expression and purification: A comprehensive review of affinity tags and microbial applications. Biotechnol. J. 7, 620-634. 